7 Nikoskelainen, E., et al., Acta Neurologica Scandinavica, 1975, 51, 347.

${ }^{8}$ Link, H., Norrby, E., and Olsson, J.-E., New England fournal of Medicine, $1973,289,1103$.

- Arnason, B. G. W., et al., fournal of the Neurological Sciences, 1974, 22, 419.

10 Platz, P., et al., Lancet, 1975, 1, 520.

11 Bradley, W. G., Diseases of the Nervous System, 1968, 29, 668.

12 Ellenberger, C., Keltner, J. L., and Burde, R. M., Archives of Neurology, 1973, 28, 182.

13 Schlezinger, N. S., and Thompson, R. A., Neurology, 1967, 17, 782

14 Percy, A. K., et al., Archives of Neurology, 1971, 25, 105.

15 Bradley, W. G., and Whitty, C. W. M., fournal of Neurology, Neurosurgery and Psychiatry, 1968, 31, 10.

${ }^{16}$ McAlpine, D., Lumsden, C. E., and Acheson, E. D., Multiple Sclerosis: a Reappraisal, 2nd edn. London, Churchill Livingstone, 1972.

17 Fog, T., and Linneman, F., Acta Neurologica Scandinavica, 1970, suppl. 47.

\section{Blowing in the Wind}

On the same day as a recent newspaper report ${ }^{1}$ appeared with the heading "Hang gliding supporters happy about safety" an article in F.A.M.A. ${ }^{2}$ described four deaths from the sport. Taking a risk has always had its attractions, so that the two reports are not incompatible, but they do serve to draw attention to the fast growing popularity of a pastime that in various forms has a history stretching back over centuries and in its present form has been described as "a high-risk leisure-time activity."3

A hang glider consists of a sail spread over a more or less rigid triangular frame. Models vary in the complexity of their construction and in the provision made for control of the flight. In the simplest forms this is done by body movements alone. The machine is therefore a kite rather than a parachute, and the pilot sits or lies prone in a harness beneath it. To launch himself he usually runs a short distance down a steep hill and pushes forward a control bar, then eases it and floats away. To land he brings the glider down nearly parallel to the ground, and if all goes well he almost comes to a halt in the air as he touches down. ${ }^{4}$

The first need is for technically faultless equipment. In this as in many other ways the clubs now springing up can have a healthy influence in seeing that their members use wellconstructed gliders, which will nearly always mean gliders commercially made by a few firms. The choice of flying site is not so easy as would first appear ${ }^{4}$ and requires experienced judgement. But perhaps the most difficult question that every hang glider must answer is whether the weather is suitable when he wants to take off. Here the experience that clubs accumulate can be of enormous help to novices. For undoubtedly the gusty days that make up so much fine weather in Britain must offer hazards as well as thrills. A further and equally important influence on the pilot's safety must be his own personality. Many people are by nature rash, or easily upset by quarrels, or prone to show off to their friends. Perhaps the least of the natural hazards is inexperience. Of the four men whose deaths are reported by Krissoff and Eiseman, ${ }^{2}$ three were exceptionally experienced and one moderately so. What seemed to contribute mainly to their deaths were, in one case each, taking a great risk deliberately, emotional upset because of a break-up with the girl friend, a rash decision to fly in turbulent wind, and drinking alcohol before flying.

In Paris at the end of June the first international meeting of hang glider pilots formed the Commission of Hang Gliding, ${ }^{5}$ which now awaits formal acceptance by the Federation Aeronautique Internationale. One way in which this commission can help to promote safety is through the rules it permits for competitive hang gliding. Some forms of competition are more dangerous than others, and if needless risk of this kind is debarred from international recognition it will soon be discouraged in the clubs. There was evidence at the meeting that the commission is already looking in this direction.

1 The Times, 14 July 1975.

${ }^{2}$ Krissoff, W. B., and Eiseman, B., Fournal of the American Medical Association, 1975, 233, 158.

3 Eiseman, B. Fournal of the American Medical Association, 1975, 233, 171.

4 Jarrett, P., and Kent, D., Flight International, 14 May 1974, p. 593.

5 Flight International, 17 July 1975, p. 77.

\section{Retirement of Editor}

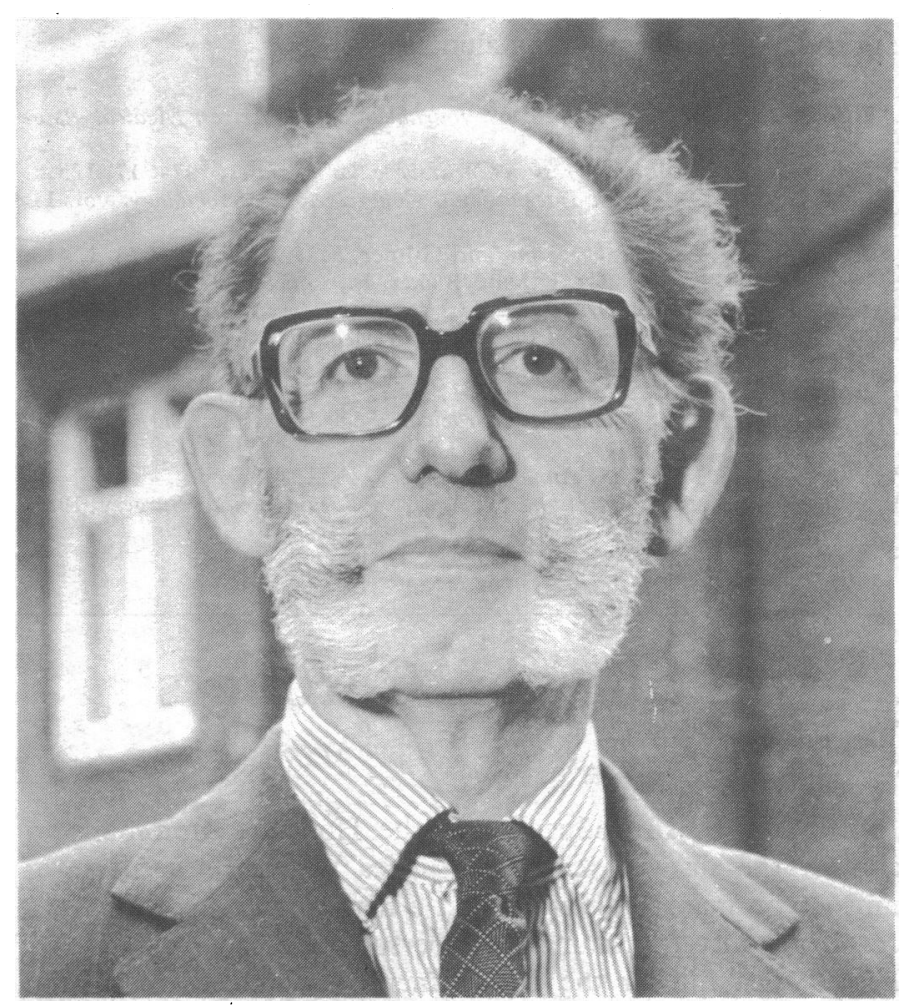

After serving as Editor of the $B$. $M . \mathcal{F}$. for nine and a half years Dr. Martin Ware retired this week. In several ways these years have brought substantial changes in the way the journal attempts every week its task of providing something for everyone. Most notably the middle pages have given space to a much greater variety of articles on administrative, social, and economic themes than formerly, for these aspects of medicine have become inseparable from so much of today's practice. At the same time the Supplement has developed a more newsy, selective, and at times personal idiom to lighten its reports of medical politics. But the main burden of editorship has perhaps been less evident to many readers. Two changes of printers have had to be undertaken-always a traumatic experience for editorial staffs. A long libel action had to be defended to vindicate the right of the medical press to publish in good faith articles of scientific importance to doctors. And latterly the evils of inflation accompanied by staggering rises in costs have added their worries to the more conventional vexations that irate authors (or failed authors) lay up for the editor. In recognition of his work the Association has made Dr. Ware a vice-president, and the good wishes of innumerable friends will go with him in his retirement. His successor is Dr. Stephen Lock (page 316). 